\title{
INFLUENCE OF SOWING DATE AND NITROGEN FERTILIZATION ON YIELD AND ITS COMPONENTS IN SOME BREAD WHEAT GENOTYPES
}

\author{
ABDEL NOUR, NADYA A. R. ${ }^{1}$ AND HAYAM, S. A. FATEH ${ }^{2}$
}

1. Field Crops Research Institute, ARC, Giza, Egypt.

2. Lab. for Design and Statistical Analysis Research, ARC, Giza, Egypt.

(Manuscript received 26 April 2011)

\begin{abstract}
Two Field trials were conducted at kafr El- Hamam Sharkia (Egypt) Agricultural Experimental Research Station during $2008 / 2009$ and 2009/2010seasons. The objective of this investigation was to study the effect of sowing dates (recommended and late) and rates of 25,50 and75 kg N/ fedan on yield and component of eight wheat genotypes, i.e. Gemmeiza $9 /$ Dovin-2, Sakha 93/ Dovin-2, Giza 168/ Dovin-2, Dovin-2, Shandaweel 1, Gemmeiza 10, Sides12 and Sakha 93. The results showed that all the studied traits were significant in the recommended compared to the late dates planting. Number of days to heading decreased when the sowing date was delayed. The earliest genotype for heading date was Sakha 93, while the genotypes Gemmeiza 9/Dovin-2 and Sakha 93/ Dovin-2 were the latest for this trait. The recommended sowing date produced the highest number of spikes $/ \mathrm{m}^{2}$, number of kernels/spike, 1000 kernel weight, biological yield and grain yield. Genotypes Sakha 93/Dovin-2, Giza 168/Dovin-2, Dovin-2 and Gemmeiza 10 gave the greatest value of number of spike/ $\mathrm{m}^{2}$, number of kernel/ spike, 1000- kernel weight, biological yield and grain yield. Heading date, days to maturity, number of spikes $/ \mathrm{m}^{2}, 1000$ - kernel weight, biological yield and grain yield were increased with the increments of nitrogen application levels up to $75 \mathrm{~kg} \mathrm{~N} / \mathrm{fed}$. The interaction between sowing date and cultivars had significant effect for all studied traits. However, the interaction between sowing dates and nitrogen fertilizer levels was significant for all characters except number of kernels/spike, plant height and 1000-kernel weight. The interaction between sowing date, genotypes and nitrogen fertilizer levels was significant for all characters except plant height, 1000kernel weight and biological yield. Furthermore, factor analysis determined three hidden factors by extraction of static roots and also by principal components analysis which justified $75.75 \%$ of data variation as a whole. The first factor with the most percent of justified variance of data and was called effective factor to yield. The second factor included genotypes and third factor included nitrogen fertilizer. The finding of this investigation may help both biologists and breeders in determining traits that could be selected for high yield.
\end{abstract}

Key words: Bread wheat, Genotypes, Sowing date, Hidden Factors 


\section{INTRODUCTION}

Wheat is the most widely cultivated of all the cereals and is a major source of nourishment. Wheat is sown in winter months in Egypt and has its own definite requirements for temperature and light. Too early sowing produces weak plants with poor root system. In addition, during too early sowing the temperature is above the optimum, which deals to irregular germination caused by frequent death of embryos and decomposition of endosperm due to bacteria or fungi. Late sowing reduces 1000 grain weight, high $\mathrm{N}$ rate increased lodging and diseased incidence but also increased protein yield (Mazurek and Kus, 1991).Late planting resulted in poor tillering and more chances of winter injury (Joshi et al., 1992).Ayoubet al (1994), indicated that split application of $\mathrm{N}$ fertilizer has been found effective in increasing crop yields compared with full application of $\mathrm{N}$ fertilizer. Hameed et al (2004), concluded that increasing $\mathrm{N}$ rate increased number of tiller per plant and spikes number per $\mathrm{m}^{2}$ but number of grains per spike and 1000- grain weight were not changed. They found that grain yield increased with increasing nitrogen application. Grain yield, spikes $/ \mathrm{m}^{2}$ and lodging increased with increasing $\mathrm{N}$ rate. On the other hand, days to emergence, emergence $/ \mathrm{m}^{2}$, tillers $/ \mathrm{m}^{2}$, days to heading and plant height were significantly affected by different planting dates, seed rates and nitrogen levels while the effect of planting dates and nitrogen levels was significant on days to maturity, 1000 grain weight and grain yield. Plants treated with $160 \mathrm{~kg} \mathrm{~N} /$ ha recorded maximum days to emergence, emergence $/ \mathrm{m}^{2}$, tillers $/ \mathrm{m}^{2}$, days to maturity, plant height and grain yield.Tammam and Tawfelis (2004), observed that normal sowing gave higher grain yields than late sowing. For growing healthy plants, there is a need to provide balanced nutrients for which an integrated management is an essential part. Higher doses of $\mathrm{N}$ increased lodging while no $\mathrm{N}$ application decreased the yield, tillering, spike length and number of grains per spike. They also, indicated significant differences among cultivars and nitrogen fertilization. Nitrogen levels up to $150 \mathrm{~kg} \mathrm{~N} /$ Fed gave the highest grain yield. As well as, the results showed that all the studied traits were significantly higher in the recommended sowing date compared to the late planting. Number of days to heading decreased when the sowing date was delayed. Ealy sowing date produced the highest number of spikes $/ \mathrm{m}^{2}$, number of kernels/ spike, 1000 kernel weight, biological yield and grain yield. Also, heading date, number of spikes/ $\mathrm{m}^{2}$, number of kernels / spike, 1000 kernel weight, biological and grain yield $t$ / ha were increased with the increments of nitrogen application levels up to $100 \mathrm{~kg} \mathrm{~N} /$ fed. However, the results obtained from plants supplied with $75 \mathrm{~kg} \mathrm{~N} /$ fed up to $50 \mathrm{~kg} \mathrm{~N} /$ fed were not significantly different from those provided with $100 \mathrm{~kg} \mathrm{~N} /$ fed except for the number 
of spikes $/ \mathrm{m}^{2}$.The interaction between sowing date and cultivars had significant effect for all the studied traits. However, the interaction between sowing dates and nitrogen fertilizer levels was significant for heading date biological yield and grain yield / ha. Furthermore, the interaction between sowing date, genotypes and nitrogen fertilizer levels was significant for number of kernels per spike, biological and grain yield t/ha.Proticet al (2007), indicated that on average over all sowing dates and fertilizer rates, highest test was observed at 60 and $90 \mathrm{~kg} \mathrm{~N} / \mathrm{ha}$ while the increase of $\mathrm{N}$ rates over these values led to an insignificant decrease of test weight in all studied varieties.

The aim of the this study is to study the effect of sowing dates, nitrogen fertilizer rates and genotypes on wheat grain, as well as, factor analysis was used to evaluate and comprehend complex relations of traits, as well as to identify the hidden factors. This analysis performed for the measured traits by principal components in the stress conditions and then the factors rotation performed by varimax rotation. Also, factor analysis was used to provide understanding for the deep structure of data because the correlation coefficients will not be beneficial due to several multivariate statistical analyses, although it may complete the information on the relationship between different traits. (Jardine et al. (1963) and Cattell (1965)).

\section{MATERIALS AND METHODS}

Two field experiments were conducted at kafr El- Hamam, Sharkia (Egypt) during the two successive season of 2008/2009 and 2009/2010 to study the effect of two sowing dates under three different nitrogen levels on yield and yield components of eight wheat genotypes. The treatments studied were: Two sowing dates i.e. $25^{\text {th }}$ of November (Normal date) and $25^{\text {th }}$ of December (Late date),eight Wheat genotypes namely Gemmeiza 9/Dovin-2, Sakha93/ Dovin-2, Giza 168/Dovin-2, Dovin-2, Shandaweel 1, Gemmeiza 10, Sides12 and Sakha 93three nitrogen fertilizers rates i.e. 25,50 and75 $\mathrm{kg} \mathrm{N} /$ fed.

These treatments were arranged in split-split-plot design with three replications. Sowing dates represented in the whole- plot, while eight wheat genotypes randomly distributed in the sub plots and the three nitrogen fertilizer levels were allocated in the sub- sub plots. Each plot consisted of 12 rows, 4 mlong and $20 \mathrm{~cm}$ apart, plot size was $9.6 \mathrm{~m}^{2}$. 


\section{Mechanical and Chemical analysis}

Soil characterization for the two experiment sites during 2008/2009 and 2009/2010 are listed in Table 1.Phosphorous fertilizer (15kg $\mathrm{P}_{2} \mathrm{O}_{5} /$ fed) as calcium super phosphate $\left(15 \% \mathrm{P}_{2} \mathrm{O}_{5}\right)$ was added with land preparation.

Table 1. Mechanical and Chemical analysis of the Soil *at the experimental farm of ARC in the Kafer El- Hamam, Sharkia (Egypt) in 2008/2009 and 2009/2010 seasons.

\begin{tabular}{|l|l|l|}
\hline \multicolumn{2}{|l|}{ 2008/2009 } & $\mathbf{2 0 0 9 / 2 0 1 0}$ \\
\hline \multicolumn{2}{|l|}{ Characteristics } & \multicolumn{2}{l|}{} \\
\hline Chemical analysis & 0.56 & 0.56 \\
\hline $\mathrm{pH}$ & 8.6 & 8.60 \\
\hline Kppm & 57.0 & 62.5 \\
\hline P ppm & 4.9 & 4.1 \\
\hline N ppm & 17.5 & 14.5 \\
\hline Mechanical analysis & \multicolumn{2}{|l|}{} \\
\hline Fine sand \% & 29.5 & 26.9 \\
\hline Silt\% & 24.7 & 30.5 \\
\hline Clay\% & 45.8 & 40.91 \\
\hline Soil texture & Clay & Clay \\
\hline
\end{tabular}

*Methods described in A.O.A.C.C. (1955) were applied

\section{Studied Characters}

1- Days to heading: estimated as the number of days from sowing to $50 \%$ heading.

2- Days to physiological maturity, :.e from anthesis to yellow ripe stage.

3- Plant height $(\mathrm{cm})$ : determined at harvest time.

4- Number of spikes $/ \mathrm{m}^{2}$ : determined at harvest time.

5- Number of kernels / spike: determined at harvest time.

6- 1000- Kernel weight ( $\mathrm{g})$ : determined at harvest time.

7- Biological yield (ton/h)

8- Grain yield (ton/h)

The data collected during the experiment were analyzed according to splitsplit- plot design, least significant differences (LSD) test was applied (Steel and Torrie, 1980). The relation of 11 plant characteristics to yield of grain also was computed. Factor analysis was performed by varimax factorial rotation via Kaiser Criteria. Data were analyzed by using soft wares like MSTAT- C and SPSS11. 


\section{RESULTS AND DISCUSSION}

\section{1- Days to heading}

Data concerning days to heading are presented in Table2. Statistical analysis of the data revealed that days to heading were significantly $(P \leq 0.05)$ affected by different sowing dates. Also genotype $x \mathrm{~N}$ levels interaction effect was highly significant. It is clear from the mean values of the data that sowing date on $25^{\text {th }}$ November showed maximum days to heading, while those sown on $25^{\text {th }}$ December exhibited minimum days to heading. It varied from 98.99 to 88.89 days in the first season and from 92.49 to 89.21 days in the second season. Days to heading for the eight genotypes over the two dates revealed that genotype Sakha 93 was the earliest one and (Gemmeiza 9/Dovin 2), (Sakha 93 / Dovin 2) and (Giza 168/ Dovin-2) were the latest cultivars. These findings may be due to the fact that heat units and the accumulated metabolites required for wheat flowering were reduced in late sowing and the atmospheric temperature starts rising up. Kheiralla and Sherif (1992), stated that delaying the planting date in relation to favorable date reduced the number of days from sowing to heading in wheat plant. The average number of days to heading were $94.50,93.85$ and 93.46 days in the first season and $91.83,90.63$ and 90.08 days in the second season with 75,25 and $25 \mathrm{~kg} \mathrm{~N} /$ fed, respectively. These results may be attributed to increasing nitrogen fertilizer rates increased vegetative growth, rates and delayed heading. These results are in harmony with those obtained by Tammam and Tawfelis (2004).On the other hand, sowing dates, genotypes and $\mathrm{N}$ levels and their interaction had a significant $(P \leq 0.05)$ effect on days to heading in two seasons except SXGXN interaction in the first season (Table2). Mean values of the data indicated that maximum days to heading were produced from Gemmeiza 9/Doven-2, Sakha 93/ Dovin-2 and Giza 168/ Dovin-2 fertilizer by at 75kg N / fed in the two seasons. Similar results were also reported by Tammam and Tawfelis (2004).

\section{2- Days to physiological maturity}

Data presented in Table 3 indicate that different planting dates, genotypes and $\mathrm{N}$ levels and all interactions had highly significant effect, except SxG interaction in first season which had insignificant effect on days to maturity. These variations in days to maturity may be due to the change in temperature and light intensity. Hameed et al (2004) concluded that longer period to maturity was shown by early crop sowing. Maturity of the crop was delayed when increasing $\mathrm{N}$ levels. Plots received $75 \mathrm{~kg} \mathrm{~N} /$ fed gave maximum days to maturity. Similar results were also reported by Hameed et al (2004). Moreover, the obtained results indicated that genotypes were almost equal in their days to maturity in both seasons. 
INFLUENCE OF SOWING DATE AND NITROGEN FERTILIZATION ON YIELD AND ITS COMPONENTS IN SOME BREAD WHEAT GENOTYPES

Table 2 
Table 3 


\section{3- Plant height (cm)}

Means presented in Table 4 show that plant height was significantly $(P \leq 0.05)$ affected by sowing dates and genotypes and their interaction in the first season, while in the second season all studied factors and the SxG interactions had a highly significant effect. Sowing on November $25^{\text {th }}$ produced taller plants when compared with the other planting date. This could be due to that long plant duration gave a maximum vegetative growth when planting was carried out earlier. Decreasing in plant height with delaying in sowing date was also reported by Hameed et al (2004). When different genotypes were taken into account, it was observed that Gemmeiza 9/ Dovin-2, Sakha 93/ Dovin-2 and Giza 168/ Dovin-2 recorded a maximum plant height when compared with other genotypes. Plant height was increased by increasing $\mathrm{N}$ levels and this was clear in the $2^{\text {nd }}$ season. These findings are confirmed by those of Ahmad et. al. (1994) and Hameed et. al. (2004).

\section{4- Number of spikes $/ \mathrm{m}^{2}$}

The results in the first season, revealed that number of spikes/ $\mathrm{m}^{2}$ was significantly increased in optimum sowing date as compared with late sowing with an average being 412.06 and 372.94 in the first and second sowing date, respectively while in the second season, the number of spikes $/ \mathrm{m}^{2}$ was 400.30 and 375.94 in the first and second sowing date, respectively (Table 5). This could be due to that the climatological conditions prevailing during the recommended sowing date favored the production of fertile tillers. These results are in general agree with those reported by Tammam and Tawfelis (2004). The genotypes Shandaweel 1, Dovin-2, Gemmeiza 9/ Dovin-2 and Gemmeiza 10 genotypes produced higher number of spikes/ $\mathrm{m}^{2}$ than Sakha 93/ Dovin-2 and Sides 12 in the first season. While Sides 12, Dovin-2 and Sakha93/ Dovin-2 produced higher number of spikes $/ \mathrm{m}^{2}$ in the second season. Increasing nitrogen fertilizer rate from

25 to $50 \mathrm{~kg} \mathrm{~N} /$ fed significantly increased average number of spikes/ $\mathrm{m}^{2}$. Increasing nitrogen fertilizer rate from 50 up to $75 \mathrm{~kg} /$ fed significantly increased number of spikes in the first season. In the second season, there was a significant difference between all $\mathrm{N}$ levels. Increasing $\mathrm{N}$ levels significantly increased number of spikes/ $\mathrm{m}^{2}$ due to the ability of wheat plants to produce more tillers and consequently more spikes. Similar results were obtained by Tammam and Tawfelis (2004).

\section{5- Number of kernels/ spike}

The means of number of kernels/ spike indicated that different sowing dates, genotypes and $\mathrm{N}$ levels and their interactions except SXN in the first season and SXG, 
Table 4 
INFLUENCE OF SOWING DATE AND NITROGEN FERTILIZATION ON YIELD AND ITS COMPONENTS IN SOME BREAD WHEAT GENOTYPES

Table 5 
SXN and GXN in the second season showed a significant $(P<0.05)$ effect (Table 6). The normal sowing date produced higher number of kernels/spike compared with late sowing. The average number of kernels/spike for wheat genotypes varied from 56.44 to 68.05 in the first season and from50.69 to 65.16 in the second season. The behavior of these varieties could be attributed to the different genetic systems of the studied genotypes. In the second season, increasing nitrogen fertilizer rate significantly increased number of kernels / spike and this may be due the effect of nitrogen on increasing both spike length and number of spikelets per spike and consequently giving higher number of grains per spike. These findings are in agreement with those obtained by Tammam and Tawfelis (2004).

\section{6- 1000- kernel weight (g)}

Analysis of the data indicated that different sowing dates and genotypes and $N$ levels showed a significant $(P \leq 0.05)$ effect on 1000- grain weight in both seasons while, the first season(Table 7) all the interactions had a significant effect $(P \leq 0.05)$ with one exception. On the other hand, the GXN interaction was the only one which showed a significant effect $(P \leq 0.05)$ in the second. Plots sown at

the optimum date $\left(25^{\text {th }}\right.$ November) produced heavier grains than late sown one. Similar results were also reported by Hameed et al (2004). Thousand grain weights were found to be decreased proportionally as the planting was delayed. Meanwhile, at the optimum planting, the plants had suitable and longer environmental conditions for vegetative growth, which resulted in the active photosynthesis and maximum translocation of the assimilates to the grains and thus had heavier grains. Hameed et al (2004) reported that early sowing had a compared with late sowing maximum grain weight and grain yield. Meanwhile, Sids 12 had the heaviest 1000- kernel weight being 39.579 and Shandaweel 1 had the lowest grain weight being 33.159 in the first season, and 28.21 in the second one. The results also showed that 1000-kernel weight was increased by nitrogen application up to $75 \mathrm{~kg} \mathrm{~N} / \mathrm{fed}$. These findings are supported with those obtained by El- Sayed (1990) and Tammam and Tawfelis (2004). 
INFLUENCE OF SOWING DATE AND NITROGEN FERTILIZATION ON YIELD AND ITS COMPONENTS IN SOME BREAD WHEAT GENOTYPES

Table 6 


\section{7- Grain yield ton/ha}

Yield is an important criterion in evaluating the adaptability of a crop to an environmental variation. Mean values of the data indicated that grain yield was significant $(P \leq 0.05)$ affected by different sowing dates, genotypes and fertilizer levels in the two seasons (Table8). Analysis of the data revealed that sowing at the optimum time favored the maximum partitioning of photosynthesis when compared to the late sowing and gave maximum grain yield. Furthermore, there was sufficient time available for plant growth and development at early sowing. Similar results have also been reported by Hameed et al. (2004) and Tammam and Tawfelis (2004). The average of grain yield for the different genotypes showed that the cultivar Shandaweel gave a lower yields being 3.64 and 4.28 ton/ ha in the first and second season, respectively while, the two genotypes Giza 168/ Dovin-2 and Dovin-2 gave the highest grain yield in both seasons. Increasing nitrogen fertilizer had a significant effect on increasing grain yield in both seasons. The highest grain yield of wheat crop with maximum level of $\mathrm{N}$ could be attributed to availability of plant nutrients in abundant amount resulting in more fertile tillers, longer spikes and more grains / spike, which ultimately led to a maximum grain yield. These results are confirmed by Hameed et. al. (2004) and Tammam and Tawfelis (2004), who concluded that grain yield increased with increasing fertilizer rates.

These results led to a conclusion that the two genotypes Giza 168/ Dovin-2 and Dovin-2 perform well if it is sown at $25^{\text {th }}$ November and having $75 \mathrm{~kg} \mathrm{~N} /$ fed.

\section{8- Biological yield ton /ha}

Analysis of the data concerning biological yield indicated that different sowing dates, genotypes and $\mathrm{N}$ levels showed a significant $(P \leq 0.05)$ effect(Table 9$)$. On the other hand, all interactions showed a significant effect with the exception of SGN in the Ist season and SN, GN and SGN in the second one. The average of biological yield was 15.53 and 22.16 ton/ha at the optimum sowing date in the first and the second seasons, respectively. Meanwhile, the average of eight wheat genotypes cultivars varied from 13.35 to 16.30 ton / ha and from 15.77 ton/ha to 21.74 ton/ha for Shandaweel 1 and Gemmeiza 9/Dovin-2 respectively, in both seasons. Increasing nitrogen levels increased significantly the biological yield. The favorable effect of increasing nitrogen fertilizer levels on the dry matter might be due to the fact that nitrogen fertilizer is considered as one of the essential nutrients for wheat growth and subsequently the grain and straw yield .These results are in line with those obtained by Tammam and Tawfelis (2004). 
INFLUENCE OF SOWING DATE AND NITROGEN FERTILIZATION ON YIELD AND ITS COMPONENTS IN SOME BREAD WHEAT GENOTYPES

Table 7 
Table 8 
Factor analysis complemented on the basis of special values which are larger than one and was done by considering three factors (Table 10). These three factors justified $75.75 \%$ data variation, as a whole. Selection for factors number was on the basis of Eigen roots number larger than one. Traits placed which on the subdivision of a factor with similar sign, all of them were influenced by an unknown nature in similar direction. Each factor has no individual existence, but it is resultant of processes and characteristics which were influenced by those traits (Mansouri and Ahadi, 2004). Three factors justified 75.75 percent changes among traits, as a whole (Table 10). Share of each factor from first to third is $51.32 \%, 12.84$ and $11.58 \%$, respectively. Factor analysis results show that first factor has large and positive factorial for traits like days to heading, days to maturity, plant height, number of spikes $/ \mathrm{m}^{2}$, number of kernels/spike and 1000-kernel weight, while sowing dates has negative effect. This factor can be called effective factor to yield. The second factor has a large and positive coefficient for genotypes and it can be called cultivars factor. The third factor has large and positive coefficient for $\mathrm{N}$ levels and it can be called fertilization factor (Mollasadeghi et al .2011). According to previous evaluations, the delay of planting lead to decrease in yield and its components. The factor analysis has provided by grouping nine variables into three main factors. The findings of this study may help both biologists and breeders in determining characters which could be selected for giving high yield and the best treatments can be used by the farmers in wheat field (Gholamin et. al. (2010) and Mollasadeghi et. al. (2011)). 
Table 9 
INFLUENCE OF SOWING DATE AND NITROGEN FERTILIZATION ON YIELD AND ITS COMPONENTS IN SOME BREAD WHEAT GENOTYPES

Table 10 


\section{REFERENCES}

1. Ahmad, K., M. Qasim and S. Zahir. 1994. Effect of fertility levels on the Performance of wheat varieties in Dera Ismail Khan. Sarhad J.Agric., 10:121124.

2. A. O. A. C. 1955 . Official Methods of Analysis, pp. $158-80,8^{\text {th }}$ Ed. Association of Official Agricultural Chemists, Washington, D.C.

3. Ayoub, M. S., S. Quertin, S. Lussier and D. L. Smith. 1994. Timing and levels of nitrogen fertility effects on wheat yield in Eastren Canada. Crop Sci., 34:748-756.

4. Cattel, R. B. 1965. Factor analysis: an introduction to essentials.I.The purpose and underlying models. Biometrics,21:190-215.

5. El- Sayed, E. A. M. 1990. Study of the effect of relationships between yield components in some wheat genotypes. M.Sc. Thesis, Fac. Agric. Al- Azhar Univ., Egypt.

6. Gholamin, R., Z. Mohammad and K. Majid. 2010. Factor analysis for Performance and other characteristics in durum wheat under drought stress and without stress. M.E.J. Sci.,Res., (6): 599-603.

7. Hameed, E., A. S. Wajid, A. A.Shad, B, B. Jehan and M. Tilah. 2004. Effect of different planting dates, seed rate and nitrogen levels on Wheat Asian J. plant Sci., 2(6):467-474.

8. Jardine, R., H. J. Moss and J. V. Mullaly. 1963. Wheat guality, a factor analysis of some test data. Aust.J.Agric. Res.,14:621.

9. Joshi, A. K., B. Rai and M. P. Singh. 1992. Technology for late sown wheat in Eastern Utter Pardesh. Indian Farming, 42:15-15.

10. Kheiralla, K. A. and T. H. I.Sherif. 1992. Inheritance of earliness and yield in wheat under heat stress. Assiut J.Agrig. Sci.,23:105-126.

11. Mansouri, S. and M. Soltaninajaf Ahadi. 2004. Evaluation and systemic analysis of yield relationship between its components for breeding of sesame (Sesamum indicum L.). Seed and Plant J., 20:167-149.

12. Mazurek, J. and J. Kns. 1991. Effect of nitrogen fertilizer application and sowing date and rate on yield and quality of grain of spring wheat cultivars grown afterdifferent preceding crops. Bioletyn instytutn Hodowl: Aklimatyzaeji Roslin, 177:123-136.

13. Mollasadeghi, V., S. Reza, I.A.Ali and K. Majid. 2011. Factor analysis of wheat quantitative traits on yield under terminal drought. American- Eurasian J.Agric. Environ. Sci., 10(2):157-159. 
14. Protic, R., M. Mladen, P. Nada, J. Zivota and J. predrag. 2007. The test weight of several winter wheat genotypes under various sowing dates and nitrogen fertilizer rates. Romanian Agric. Res., 43-46.

15. Steel, R. G. D. and J. H. Torrie. 1980. Principles and procedures of Statistics.Mc,GrawHil Book Co. Inc. New York.

16. Tammam, A. M. and M. B. Tawfelis. 2004. Effect of sowing date and nitrogen fertilizer levels in relation to yield and yield components of durum wheat (Triticum turgidum var,durum) under upper Egypt environments. J. Agric. Sci. Mansoura Univ., 29(10):5431-5442. 


\title{
تأثير ميعاد الزراعة ومستويات التسميد الأزوتى على المحصول و مكوناتة لبعض أصناف قمح الخبز
}

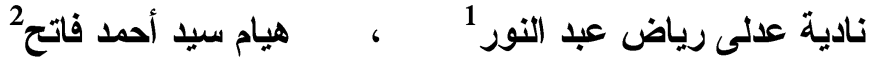 \\ , مسم بحوث القدح - معهد الدحاصيل الحقلية - مركز البحوث الزرراعبة

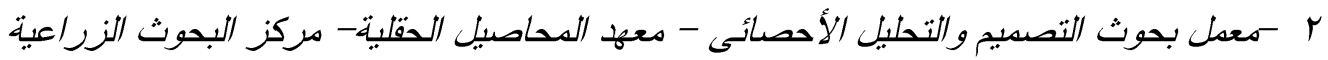

أجريت هذة الدراسة فى محطة البحوث الزراعية فى كفر الحمام شرقية خلال موسمى

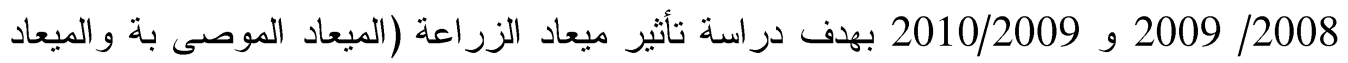

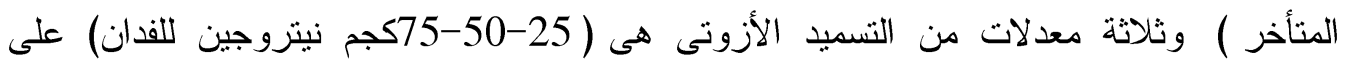

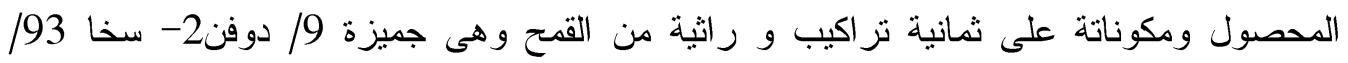

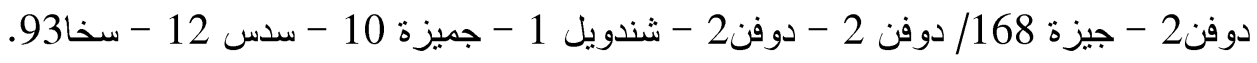
أوضخت النتائج وجود تأثير معنوى لميعاد الزر اعة المبكرعلى كل الصفات المدروسة مقارنة

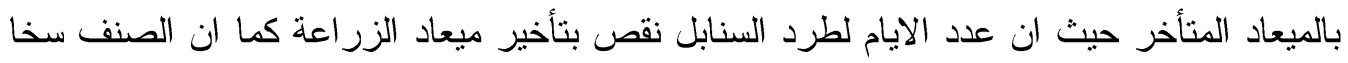

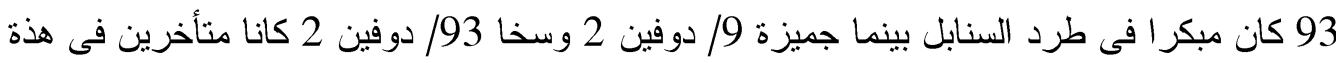

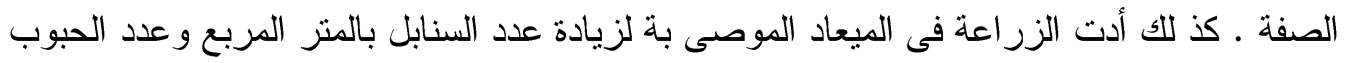
بالسنبلة ووزن الألف حبة والمحصول البيولوجى ومحصول الحبوب كذلك أعطت الأصناف سخا

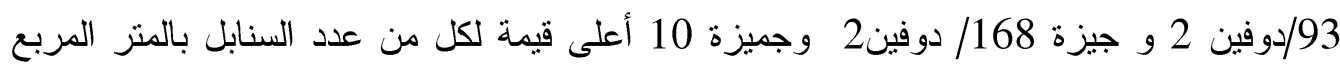
و عددالحبوب بالسنبلة ووزن الألف حبة والمحصول البيولوجى ومحصول الحبوب. وقد أدى زيادة معدل السماد الأزوتى الى 75 كجم نيتروجين للفدان الى زيادة معنوية لكل من عدد الأيام لطرد

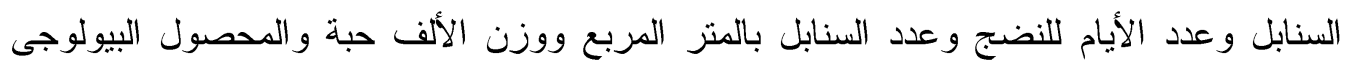

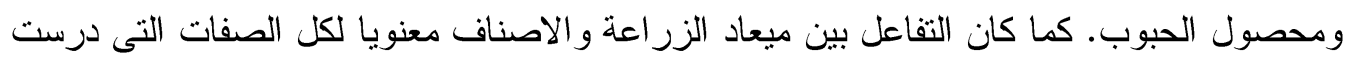

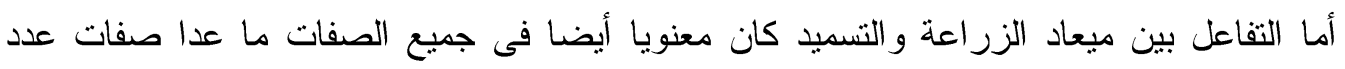

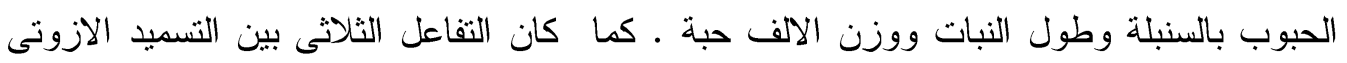
و الاصناف معنويا أيضا فى جميع الصفات ماعدا طول النبات ووزن الالف حبة و المحصول

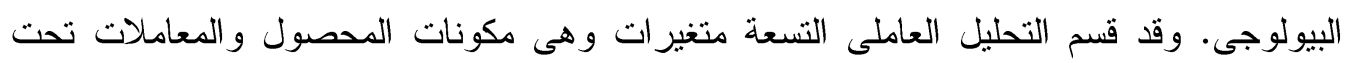

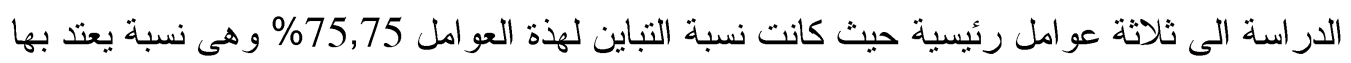
و هذة العوامل تؤثز على أنتاجية محصول القمح وقد شمل العامل الأول ميعاد الزراعة ولية وصنات

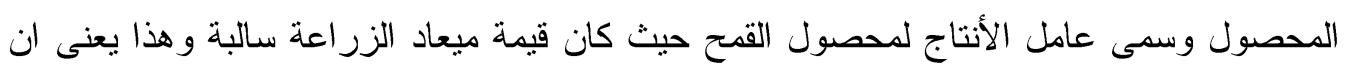

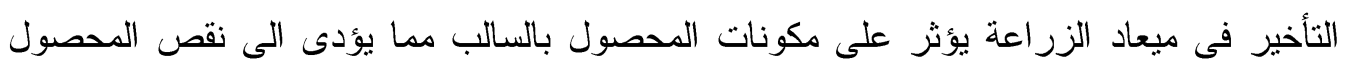

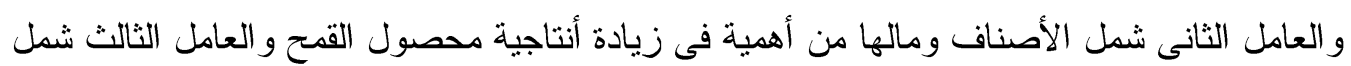

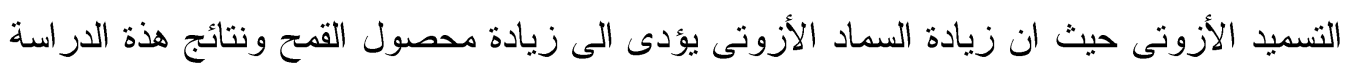

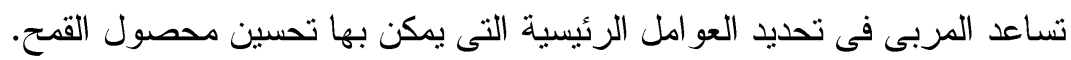

